\title{
THE EDUCATIONAL ROLE OF THE ACCOUNTANTS ASSOCIATION IN POLAND (AAP) AFTER THE DEREGULATING OF THE PROFESSION
}

\author{
Katarzyna Świetla \\ Cracow University of Economics, Cracow, Poland \\ e-mail: kswietla@uek.krakow.pl
}

(C) 2018 Katarzyna Świetla

This is an open access article distributed under the Creative Commons Attribution-NonCommercial-NoDerivs license (http://creativecommons.org/licenses/by-nc-nd/3.0/)

DOI: 10.15611/fins.2018.2.06

JEL Classification: M41, I25

\begin{abstract}
Due to the commonly perceived need to specialize in one professional activity, the role of education is increasing. This includes accounting specializations which are important as professions of public trust. In connection with such expectations, the role of education among professional groups of accounting professionals at all levels is increasing. The article presents the educational requirements for the professional specialization on accounting against the IFAC International Education Standards and in the context of the deregulation of the accountancy professions in Poland. As a solution to the problems of appropriate education, the role of the Accountants Association in Poland (AAP) was pointed out, based on the courses provided by it, aimed at not only improving the qualifications of the individuals who are involved in accounting professionally, but also on the supporting ethics. The courses taught were analyzed in a cross-section of their participants in the years 2013-2016. The method adopted to achieve the intended purpose was the analysis of the available literature, the laws in force and the sources provided by the AAP. On the basis of the research, it was found that despite the absence of mandatory professional certification for accounting and bookkeeping, the professionals in this area do see the need for continuous education and take diverse action to raise the quality of the services they provide.
\end{abstract}

Keywords: accounting, continuous training, education, certification, professional training.

\section{Introduction}

According to the maxim that says "if you are not moving forward, you are moving backwards", we should turn our attention onto the widely perceived need for the constant operation of accounting processes. Due to the commonly perceived need to specialize in one's professional activity, the role of education is increasing. This includes accounting specializations which are important as professions of public trust. Undoubtedly, knowledge of accounting has gained importance in the wake of the financial crisis that engulfed the world in the first decade of the twenty-first century, causing the destruction of a system built over many years. 
In connection with the expectations of the modern market, the role of education among professional groups of accounting professionals at all levels is increasing. Moreover, this role is conditioned by the rapid evolution of the applied solutions which requires accounting professionals to continuously train in order to maintain the high quality of knowledge and experience. Such an approach poses new challenges for accountants, forcing them to make the effort for society as well as the actions required to broaden their knowledge and maintain their competence [Micherda 2009].

The article presents the educational requirements for the professional specialization on accounting against the IFAC International Education Standards, and the approach described as life-long learning, with a special focus on the context of the deregulation of the accountancy professions in Poland. As a key entity having an impact on the problems of appropriate education, the role of the AAP was pointed out, based on the courses provided by it, aimed at not only improving the qualifications of the individuals who are involved in accounting professionally, but also on the supporting ethics. The courses taught were analyzed in a cross-section of their participants in the years 2013-2016.

The method adopted to achieve the intended purpose was the analysis of the available literature, the national and international laws in force and the sources provided by the AAP.

\section{Educational requirements regarding professional specialization in contemporary accounting}

According to the opinion of B. Micherda: "The education and practice of professional accountants should lay the foundations of professional knowledge and values, ethics and professional attitudes that allow accountants to continue learning and adapting to change throughout their professional lives" [Micherda 2010]. This position is conducive to the proper and ethical approach to the problems faced by accountants in the modern economy and it determines the appropriate action to address them in order to solve them properly. A derivative of such an approach is the widely perceived need to have the appropriate competencies by accountants, which became the basis for the development of the educational standards by the International Federation of Accountants (IFAC). The International Accounting Education Standards Board (IAESB) is an independent standard-setting body that serves the public interest by establishing standards in the area of professional accounting education that prescribe technical competence and professional skills, values, ethics, and attitudes [www. iasb.org].

They significantly affect the "world development and raising the rank of accounting professions ... in order to provide services at a high level for the benefit of all" [www.ifac.org]. As noted by M. Kwiecien, it is the regulation of the educational standards for professional accountants that shall determine the greatest changes in 
accounting knowledge [Kwiecień, www.fundacja.edu.pl]. It should also be pointed out that professional competence means the ability to carry out tasks in accordance with the specified standard and they also exceed the knowledge of the principles, rules, norms, concepts, facts and procedures and means the ability to integrate and use professional skills and values, ethics and attitudes.

Moreover, thanks to the implementation of the International Education Standards (IES), the basic differences on the international scene in terms of requirements for the accounting profession are being bridged. This is conducive to the mobility of persons who are employed in accounting occupations while maintaining international norms of good practice for professional training in the area of accounting [www.ifac.org].

The IAESB conducts its educational activities by means of the broad implementation of the International Education Standards (IES), which increase the competence of the accountancy profession globally. This leads to raising the trust of the customers towards the accounting profession.

Table 1. International Educational Standards of IFAC

\begin{tabular}{|c|l|l|}
\hline $\begin{array}{c}\text { Standard } \\
\text { Number }\end{array}$ & \multicolumn{1}{|c|}{ Standard title } & Date of entry into force \\
\hline IES 1 & Entry Requirements to Professional Accounting Education & July 1, 2014 \\
\hline IES 2 & $\begin{array}{l}\text { Initial Professional Development-Technical Competence - } \\
\text { IFAC }\end{array}$ & July 1, 2015 \\
\hline IES 3 & Initial Professional Development-Technical Competence & July 1,2015 \\
\hline IES 4 & $\begin{array}{l}\text { Initial Professional Development-Professional Values, Ethics } \\
\text { and Attitude }\end{array}$ & July 1, 2015 \\
\hline IES 5 & $\begin{array}{l}\text { Practical Experience Requirements for Aspiring Professional } \\
\text { Accountants }\end{array}$ & July 1, 2015 \\
\hline IES 6 & $\begin{array}{l}\text { Initial Professional Development - Assessment of Professional } \\
\text { Competence }\end{array}$ & July 1, 2015 \\
\hline IES 7 & Continuing Professional Development & January 1,2014 \\
\hline IES 8 & $\begin{array}{l}\text { Professional Competence for Engagement Partners Responsible } \\
\text { for Audits of Financial Statements }\end{array}$ & June 1, 2016 \\
\hline
\end{tabular}

Source: author's own research based on: [www.ifac.org].

The standards presented in Table 1 are intended to unify the accounting requirements both in terms of the area of knowledge, competence and ethics, thus ensuring their potential customers about the professionalism of the accounting personnel.

On 2 December 2015, the International Accounting Education Standards Board (IAESB) published a Consultation Paper entitled Meeting Future Expectations of Professional Competence: A Consultation on the IAESB's Future Strategy and Priorities [www.ifac.org]. This document presented the proposed vision and strategy 
for the next five years that builds on the completion of its newly revised International Education Standards. It is also prepared to support the implementation of these standards. This was followed by the 2017 Education Handbook which contains the IAESB's suite of the revised and redrafted International Education Standards (IES) 1-8. It also contains:

- Framework for International Education Standards for Professional Accountants and Aspiring Professional Accountants,

- description of levels of proficiency,

- drafting conventions,

- glossary of terms [Handbook of International... 2017].

On the basis of convergence, this leads to the creation of unified professional titles related to the performance of tasks, such as accounting in different countries. ${ }^{1}$

At the same time it should be stressed that knowledge once acquired does not ensure success in the modern economy which is subject to continuous evolution especially in the context of its regulation, e.g. in accounting it is necessary to train continuously. Against that background, it is worth noting that lifelong learning is a process of constant renewal, improvement and development ongoing throughout the person's life. In other words, it requires lifelong learning (LLL), referred to as ustawiczne dokształcanie zawodowe (UDZ) in Poland, understood as a cognitive activity for the deepening of knowledge, skills or competence (for personal, social or professional reasons) [Tissot 2004].

A memorandum on the need for lifelong learning was issued by the European Commission in 2000. Lifelong learning was defined as: "All learning activity undertaken throughout life, with the aim of improving knowledge, skills and competences within a personal, civic, social and/or employment-related perspective" [Memorandum on life... 2000]. According to these assumptions, lifelong learning includes basic and advanced skill improvement.

Adopted in 2000 as part of the Lisbon Strategy, the program to raise the dynamics of economic and social development of the EU is constantly continued in line with the Europe 2020 strategy. This includes, for example, promotion of changes in education and training systems towards systems that would facilitate and support learning throughout life. With the development of this idea the general rules of LLL policy that apply to the different levels of administration in the Member States (central, regional and local) and for different forms of education were established.

Poland also participates in selected activities for learning throughout life, and it has implemented a number of programs to reform individual areas of Polish education. This was a result of, including other factors, the recommendations of the Council of the EU Parliament and Council on the European Qualifications

${ }^{1}$ In Poland, the relevant regulations are found in the Ordinance of the Minister of Labor on the classification of professions and specializations for the needs of the labor market and its scope (Journal of Laws, 2014, item 1145). 
Framework for lifelong learning (2008). Against this background, Poland started work on developing the Polish Qualifications Framework.

In 2012, a new EU document entitled "Twelve years after" was published. It is a call for a renewed Memorandum on Lifelong Learning, which stressed that education is the key to modern Europe 2020 [Twelve years after... 2012]. This course of action was also adopted in Poland where, on the basis of the Ordinance of the Prime Minister of 12 May 2016 [Ordinance No 58, 2016], an Interdepartmental Team for learning throughout life and the Integrated Qualification System was founded. It currently includes eleven heads of ministries and one minister in the Prime Minister's Office. It is chaired by the Minister of National Education. The actions of this team focus on the implementation of the integrated Qualification System which should be consistent with the assumptions of the EU qualifications framework [Uczenie się przez... 2016].

\section{Bookkeeping services in the context of the deregulation of the accounting profession}

The accounting office is an entity engaged in the provision of the services mentioned below:

- periodic determination or checking of inventory of the actual state of assets and liabilities,

- keeping of accounting books based on accounting documents containing systematically kept records of events in chronological order,

- collection and storage of accounting documents and other documentation as provided in the Act on Accounting,

- preparing financial statements,

- valuation of assets and liabilities and for the determination of the financial result. After the deregulation of the accounting profession, since May 10, 2014 [UoR 2014], access to the bookkeeping services has been open to individuals without the certificate previously issued by the Minister of Finance. ${ }^{2}$ On the basis of the amended law, bookkeeping services can be performed by persons who:

- have full legal capacity and no criminal records for a specific catalog of offences, i.e. those affecting credibility of documents, property, business transactions, trading in money and securities, for fiscal offence and for the offence specified in par. 9 of the Act of 29 September 1994 on accounting,

- have liability insurance [Ordinance of the Minister of Finance in 2014]. ${ }^{3}$

${ }^{2}$ Despite the lack of requirement to have a certificate or diploma, those who hold such documents will be able to use them on a voluntary basis wanting to present their professional qualifications.

${ }^{3}$ An accounting office that operates only revenue and expense ledgers or assists in the performance of returns and declarations does not have to have liability insurance. 
Despite the abolition of compulsory certification, some of the people who applied for the certification had an opportunity to continue the process. This applied to people who

- already begun proceedings for an accounting certificate,

- submitted an application for qualify for the examination for candidates to become certified accountants,

- applied for an accounting certificate and passed the exam or took it.

As it turned out, the need to strive for a certification of professional qualifications had not discouraged them to acquire certification (Table 2). ${ }^{4}$

Table 2. Certificates awarded after the announcement of the law on deregulation

\begin{tabular}{|c|c|c|}
\hline Year & Certificate numbers & Number of certificates \\
\hline 2014 & $64492-68433$ & 3,941 \\
\hline 2015 & $68434-69219$ & 786 \\
\hline 2016 & $69220-69242$ & 23 \\
\hline 2017 & $69343-69262$ & 20 \\
\hline
\end{tabular}

Source: author's own research based on: [http://www.mf.gov.pl].

Moreover, it should be stressed that the activity in the field of providing bookkeeping services can be performed by an entrepreneur who is a natural person or a legal person or an organization other than a legal person (provided with legal capacity by a separate act of law), performing business on their own behalf. According to the above assumptions, entrepreneurs can also include civil partners within the scope of their business activity.

In addition, bookkeeping services can also be provided by persons entered into the register of expert auditors (as of 13.11.2017, it contained 6,922 names) or the list of tax advisers (8,896 persons entered on the day 13.11.2017) and 564 entities authorized to conduct tax advisory services.

\section{Literature review}

The issue of continuing education in Poland has been taken up in numerous articles indicating its significance for the proper performance in the accounting profession. U. Drumlak, in her text "Idea kształcenia ustawicznego w zawodzie księgowego" [The idea of continuous education in the accounting profession], presented lifelong learning in Knowledge Europe based on reports of commissions appointed by international organizations [Drumlak 2011]. In addition, she assessed the offered range of continuing education for professional accountants in Poland [Drumlak 2013]. On the other hand, P. Prewysz-Kwinto and G. Voss analyzed the courses and

${ }^{4}$ Applications for certification could be submitted by August 9, 2014. 
training offered to the accountant as an element of non-formal education. They also indicated how these courses are assessed by employers from the Pomorskie and Kujawsko-Pomorskie provinces [Prewysz-Kwinto, Voss 2016].

The certification of accountants was the focus of a study by A. Buczkowska and A. Zbaraszewska, who researched accountants' training as part of the professional improvement offered to them [Buczkowska, Zbaraszewska 2011]. In recent years, this subject was also addressed by K. Świetla, who pointed to the scope and role of certification of the accounting profession in the publication titled "Outsourcing usług księgowych w świetle oczekiwań biur rachunkowych i ich klientów" [Outsourcing of accounting services in the light of the expectations of accounting offices and their customers] [Świetla 2014] and together with K. Jonas she investigated the risk of running a business activity in the context of the deregulation of the accounting profession in Poland [Świetla, Jonas 2015].

On this basis, it should be emphasized that certification as a method of education has been widely discussed in the literature but there are no studies that would indicate its reception by the stakeholders, i.e. the participants. This study is an analysis of the popularity of continuing education among accountants based on all the paths offered by AAP in Poland.

\section{Lifelong education within the framework of the Association of Accountants in Poland after the deregulation of the accounting profession (2013-2016)}

The Accountants Association in Poland offers educational services in non-public institutions of lifelong learning. They operate at the District Branches and the Institute, and their role is to educate the participants of the relevant courses in order to acquire or supplement the knowledge on the issues of accounting and financial auditing. ${ }^{5}$

As part of its offered range, the Association provides the opportunity to participate in:

a. courses in the area of acquiring professional qualifications confirmed by proper certificates (four-step educational path),

b. short courses and professional conferences,

c. courses for expert auditor candidates, post-graduate training, post-secondary education and other courses,

d. conferences and lectures.

The first (a-listed) professional qualifications are divided into four steps:

I - accountant (accounting assistant),

II - accountant (independent bookkeeper),

\footnotetext{
${ }^{5}$ Financial training paid for by the participants and those funded from EU sources were treated as one group for the purposes of this article.
} 
III - chief accountant,

IV - certified accountant [Resolution No 757/202/2010 2010].

In order to obtain the relevant professional title, the person applying for certification must meet certain criteria specified in Appendix No 1 to the Resolution No 732/111/2009 of the Board of the AAP of 20 July 2009.

In the years 2013-2016, the number of the participants in the course for candidate accounting assistants rose by $10.8 \%$ on average - from 6,310 in 2013 to 8,585 2016 (Table 3 and Figure 1).

Table 3. Participation in accounting-assistant courses in 2013-2016

\begin{tabular}{|l|c|c|c|c|}
\hline \multicolumn{1}{|c|}{ Year } & 2013 & 2014 & 2015 & 2016 \\
\hline Number of groups & 242 & 268 & 273 & 310 \\
\hline Number of participants: & 6,310 & 7,098 & 7,437 & 8,585 \\
\hline $\begin{array}{l}\text { Average number of participants } \\
\text { per group }\end{array}$ & 26.1 & 26.5 & 27.2 & 27.7 \\
\hline Number of participants y/y & - & 1.125 & 1.048 & 1.154 \\
\hline
\end{tabular}

Source: author's own work based on the AAP's own materials.

The largest annual increase (15.4\%) occurred in 2016, following the weaker 2015 (4.8\%). From year to year, both the average number of participants per group increased (from 26.1 to 27.7) as did the number of groups themselves (from 242 to 310 ).

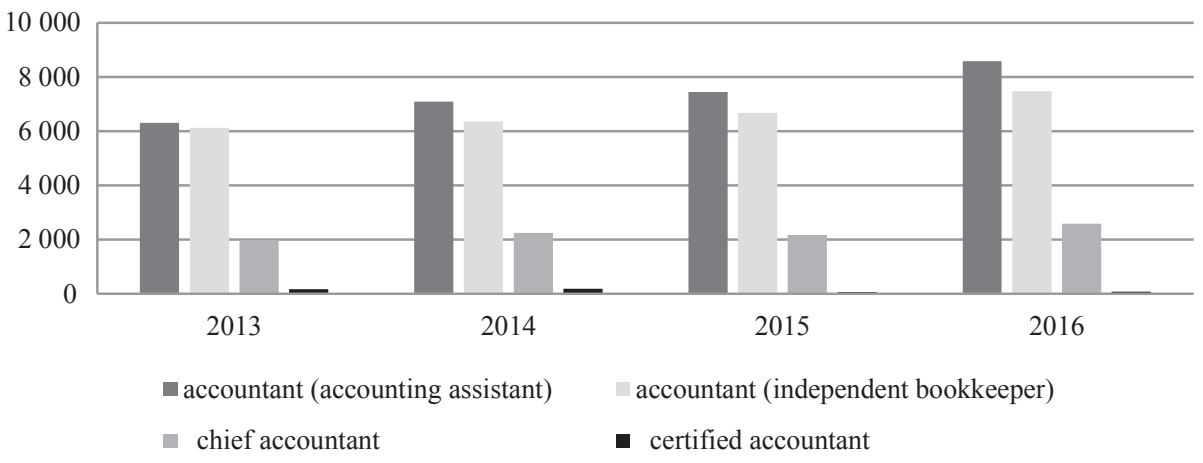

Fig. 1. The participants of the courses conducted in the years 2013-2016 in the framework of a four-track professional accountant training path.

Source: author's own work based on the AAP's own materials.

In the studied period (2013-2016), the number of courses per accounting specialist increased (Table 4 and Figure 1). The increase in the average number of participants was accompanied by an increase in the average number of participants 
per group (from 28.0 to 29.7). On average, in the studied period, the number of course participants grew by $6.9 \%$. The largest growth was recorded in the last audited year of as much as $12.0 \%$.

Table 4. Participation in accounting specialist courses in the years 2013-2016

\begin{tabular}{|l|c|c|c|c|}
\hline \multicolumn{1}{|c|}{ Year } & 2013 & 2014 & 2015 & 2016 \\
\hline Number of groups & 219 & 231 & 227 & 252 \\
\hline Number of participants & 6,125 & 6,350 & 6,675 & 7,475 \\
\hline $\begin{array}{l}\text { Average number of participants } \\
\text { per group }\end{array}$ & 28.0 & 27.5 & 29.4 & 29.7 \\
\hline Number of participants y/y & - & 1.037 & 1.051 & 1.120 \\
\hline
\end{tabular}

Source: author's own work based on the AAP's own materials.

Chief accountant courses in the studied period were held less often than assistant-accountant or accounting specialist courses (Tables 3-5 and Figure 1). At the same time we observe similar trends as before - the average number of course participants increased (from 21.4 in 2016 to 26.4 in 2016), while the number of course participants and the number of courses grew as well, from 1,993 to 2,588 and from 93 to 98, respectively. The year 2015 was an exception, as fewer courses (with fewer participants) were organized, which was the smallest number in the studied period.

Table 5. Participation in chef accountant courses in the years 2013-2016

\begin{tabular}{|l|c|c|c|c|}
\hline \multicolumn{1}{|c|}{ Year } & 2013 & 2014 & 2015 & 2016 \\
\hline Number of groups & 93 & 93 & 85 & 98 \\
\hline Number of participants & 1,993 & 2,249 & 2,178 & 2,588 \\
\hline $\begin{array}{l}\text { Average number of participants } \\
\text { per group }\end{array}$ & 21.4 & 24.2 & 25.6 & 26.4 \\
\hline Number of participants y/y & - & 1.128 & 0.968 & 1.188 \\
\hline
\end{tabular}

Source: author's own work based on the AAP's own materials.

As can be expected, certified accountant courses in the studied period were organized in an even smaller number than the other types of courses. The number of groups dropped dramatically from 14 in 2013 to 3 in 2015-2016 (Table 5 and Figure 1), with a decreasing number of course participants (from 179 in 2013 to 83 in 2016). At the same time, a significant increase in the average number of participants of the courses per group was observed (from 12.8 to 27.7). Also in this respect, 2015 was exceptional - we can note the smallest number of the participants in the certified accountant course, only 75 , which shows a dramatic drop of $60 \%$ compared to 2014. 
Table 6. Participation in courses for certification in accountancy in the years 2013-2016

\begin{tabular}{|l|c|c|c|c|}
\hline \multicolumn{1}{|c|}{ Year } & 2013 & 2014 & 2015 & 2016 \\
\hline Number of groups & 14 & 13 & 3 & 3 \\
\hline Number of participants & 179 & 185 & 75 & 83 \\
\hline $\begin{array}{l}\text { Average number of participants } \\
\text { per group }\end{array}$ & 12.8 & 14.2 & 25.0 & 27.7 \\
\hline Number of participants y/y & - & 1.034 & 0.405 & 1.107 \\
\hline
\end{tabular}

Source: author's own work based on the AAP's own materials.

The drop in the numbers of participants presented in Table 6 is due to the absence of EU funding for financing the expensive training. Moreover, such advanced training is often recognized by potential users as going beyond the needs of bookkeeping services. Its scope largely corresponds to the requirements for appointed expert auditors, who receive this professional title automatically. Thus, an expert auditor shall receive a certified accountant certificate on the basis of the powers held, unlike a certified accountant who cannot become an expert auditor on the basis of their certificate as an accountant.

Table 7. Total participation in accounting-assistant, accounting specialist, certified accountant, and chief accountant courses in 2013-2016

\begin{tabular}{|l|c|c|c|c|}
\hline \multicolumn{1}{|c|}{ Year } & 2013 & 2014 & 2015 & 2016 \\
\hline Number of groups & 568 & 605 & 588 & 663 \\
\hline Number of participants & 14,607 & 15,882 & 16,365 & 18,731 \\
\hline $\begin{array}{l}\text { Average number of participants } \\
\text { per group }\end{array}$ & 25.7 & 26.3 & 27.8 & 28.3 \\
\hline Number of participants y/y & - & 1.087 & 1.030 & 1.145 \\
\hline
\end{tabular}

Source: author's own work based on the AAP's own materials.

In the studied period, the largest number of courses were organized at the lowest level (45\% of all accounting training) and the smallest one at the highest level $(1.4 \%$ courses on average rates during the period considered, from $2.5 \%$ in 2013 to only $0.5 \%$ in 2016). Specialist accountant courses constituted $38.3 \%$ of the courses, and chief accountant courses $-15.2 \%$.

Table 7 and Figure 2 present aggregated information on courses conducted in the framework of the four-track professional accountant training path. The number of course participants in the period 2013-2016 increased by $28.2 \%$ (from 14,607 to $18,731)$.

Moreover, apart from courses within the framework of the four-step accounting career path, there were also courses certificating the professional qualifications of tax accounting specialists, HR and payroll specialist accountants, and investment 
accounting specialists, which were conducted in the following numbers per year: 2013 - 78 courses for 1,905 participants, $2014-100$ courses for 2,388 participants, 2015 124 courses for 2,943 participants and 2016 - 159 courses for 2,843 participants.

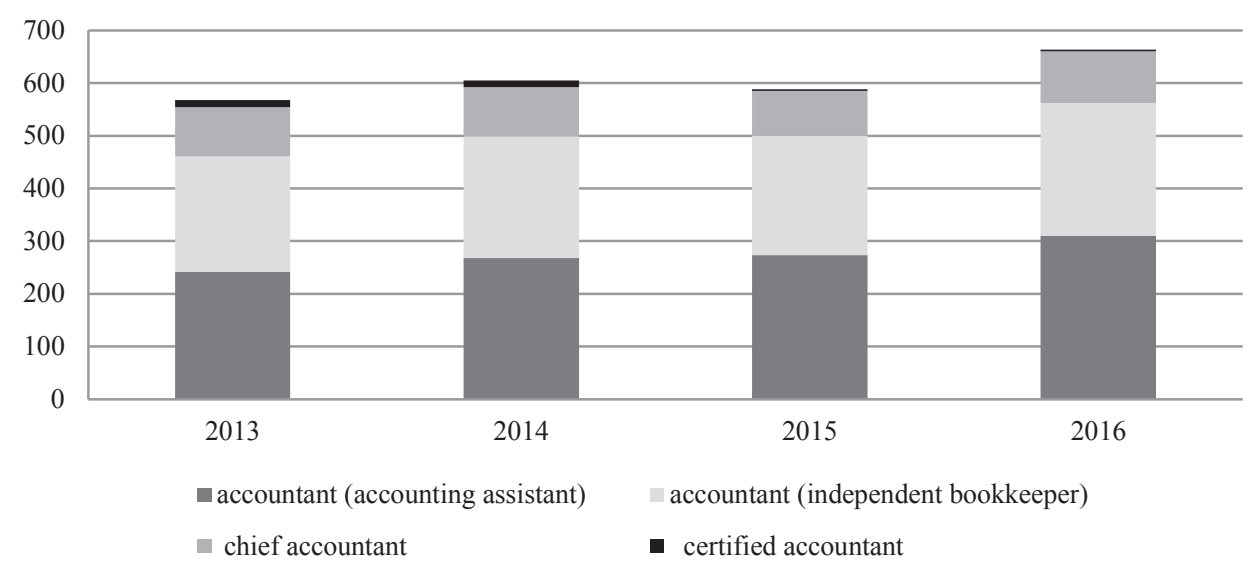

Fig. 2. Courses conducted in the years 2013-2016 in the framework of a four-track professional accountant training path

Source: author's own work based on the AAP's own materials.

Within group $b$ (short courses and professional conferences), i.e. the participants of short courses (less than 30 hours), and professional conferences, their numbers are as follows:

Table 8. Participants of short courses and professional conferences in the years 2013-2016

\begin{tabular}{|l|c|c|c|c|}
\hline \multicolumn{1}{|c|}{ Year } & 2013 & 2014 & 2015 & 2016 \\
\hline $\begin{array}{l}\text { Number of groups, including: } \\
\text { - Mandatory for expert auditors }\end{array}$ & 1,166 & 1,298 & 1,344 & 1,445 \\
166 & 169 & 152 & 142 \\
\hline $\begin{array}{l}\text { Number of courses, including: } \\
\text { - participants of mandatory courses for } \\
\text { expert auditors }\end{array}$ & 56,530 & 37,331 & 37,550 & 41,305 \\
\hline
\end{tabular}

Source: author's own work based on the AAP's own materials.

In the studied period, interest in short-term training further increased (Table 8). This is apparent in the increase in both the number of participants (from 36,530 in 2013 to 41,305 in 2016 , i.e. by ca. $13.1 \%$ ), and the number of organized professional courses and conferences (from 1,166 to 1,445). It can be seen that mandatory courses granting expert auditor certifications had a decreasing share in the total number of short-term courses (amounting to $9.8 \%$ in 2016, while in 2013 the share was 14.2\%). 
At the same time, the number of participants dropped (from 5,026 to 4,533) at the relatively steady mean number of participants per group (from 30.3 to 31.9).

Another type of training offered by the Association of Accountants in Poland are preparatory courses for candidates for expert auditors, on top of the post-graduate and post-secondary forms of education.

Table 9. Courses organized by the Accountants Association in Poland in 2013-2016

\begin{tabular}{|l|r|r|r|r|}
\hline \multicolumn{1}{|c|}{ Year } & 2013 & 2014 & 2015 & 2016 \\
\hline Number of courses & 240 & 196 & 199 & 210 \\
- including for expert auditors & 6 & 3 & 3 & 5 \\
- including postgraduate studies & 17 & 9 & 5 & 3 \\
- including certified financial services expert & & & & \\
$\quad$ courses & 0 & 0 & 1 & 3 \\
\hline $\begin{array}{l}\text { Number of courses } \\
\text { - including candidates for expert auditors }\end{array}$ & 4,859 & 4,234 & 3,787 & 4,111 \\
- including postgraduate students & 581 & 229 & 59 & 125 \\
- including certified financial services expert & & & 46 & 50 \\
$\quad$ courses & - & - & 16 & 58 \\
\hline
\end{tabular}

Source: author's own work based on the AAP's own materials.

The number of longer training also decreased, from 240 in 2013 to 210 in 2016 (Table 9). The greatest changes in this area during the period refer to the decrease in interest in post-graduate studies (a decrease in the number of participants from 581 to only 50 and the number of groups from 17 to 3, additionally, with the drop of the average number of participants from 34.2 to 16.7), starting from 2015, certified expert in financial services courses were initiated by the AAP in response to market demand. In 2015, one such course was organized for 16 people, and in 2016, with a significant increase of interest, already 3 courses for 58 people were provided.

Moreover, the Accountants Association in Poland organizes numerous scientific conferences and lectures (Table 10). In 2013-2016 a total of 1,751 such events took place.

Table 10. Conferences and lectures organized by the Association of Accountants in Poland in 2013-2016

\begin{tabular}{|l|c|c|c|c|}
\hline \multicolumn{1}{|c|}{ Year } & 2013 & 2014 & 2015 & 2016 \\
\hline Number of groups & 451 & 428 & 435 & 437 \\
\hline Number of participants & 13,743 & 12,434 & 12,246 & 12,011 \\
\hline $\begin{array}{l}\text { Average number of participants } \\
\text { per group }\end{array}$ & 30.5 & 29.1 & 28.2 & 27.5 \\
\hline Number of participants y/y & - & 0.905 & 0.985 & 0.981 \\
\hline
\end{tabular}

Source: author's own work based on the AAP's own materials. 
As can be noted in this group of courses, the interest among the participants is dropping. While in 2013 there were 451 courses for 13,743 people, in 2016 these numbers decreased to 437 training courses for 12,011 people (fewer by $3.1 \%$ and $12.6 \%$ respectively). The largest annual decline was recorded in 2014, when the number of participants fell by $9.5 \%$. For each year of the analyzed period, the average number of participants in training also dropped from 30.5 to 27.5.

On the basis of the analysis conducted, it should be emphasized that the role of the Accountants Association in Poland is unquestionably extremely important both regarding the range of offered educational services in the field of multidimensional science of accounting and the number of participants.

\section{Conclusion}

On the basis of the research, it was found that despite the absence of mandatory professional certification for accounting and bookkeeping, the professionals in this area do see the need for continuous education and take diverse actions to raise the quality of services they provide.

The basis for such a statement are the numerous courses run by the AAP, in which persons who want to acquire or deepen their knowledge in the field of accounting can participate. This applies in particular to the accounting assistant courses, where the annual number of participants increased by $10.8 \%$ on average, from 6,310 in 2013 to 8,585 in 2016. This was accompanied by a similar interest in specialist accountant courses, where the increase in the average number of participants was from 6,125 in 2013 to 7,475 in 2016 . There was also an increase in the number of participants in the chief accountant courses, from 1,993 in 2013 to 2,588 in 2016 . The only course which registered a decline in interest was the certified accountant course (from 179 in 2013 to 83 in 2016), which can be explained by the termination of the EU funding supporting the financing of this course and the possibility of obtaining the same competences by auditors. Moreover, it should be noted that short courses were very popular (a rise from 36,530 in 2013 to 41,305 in 2016), while the number of people participating in courses supporting training for candidates for statutory auditors and the interest in post-graduate studies decreased. However, regardless of the latter, the total number of people raising their qualifications has increased year by year.

Therefore, the assertion that the need to acquire knowledge and experience is not due to the imposed regulation but rather a need arising of its own implemented by specific individuals, can be undoubtedly accepted.

Deciding on training in accounting promotes the diversity of the training available, varied both in their advancement as well as the subject. This applies not only to longer courses that provide appropriate certificates and thus the power to practice, but also short themed training popularizing new solutions in the Polish market as well as specific complex issues. 
In conclusion, it must be said that human beings have an innate desire to learn from the earliest days of their life, and the practice of a profession which is a passion, as is often the case of accounting professionals, is conducive to achieving professional satisfaction.

\section{Bibliography}

Act of 29 September 1994 on Accounting, consolidated text DzU [Journal of Laws] of 2013, No. 153, item. 330, as amended

Act of 9 May 2014 on Facilitating Access to Certain Regulated Professions, DzU [Journal of Laws] item 768.

Buczkowska A., Zbaraszewska A., 2011, Certyfikacja zawodu księgowego w Polsce, Zeszyty Naukowe Uniwersytetu Szczecińskiego nr 625, Finanse, Rynki Finansowe, Ubezpieczenia, nr 32.

Consultation Paper, Meeting Future Expectations of Professional Competence $A$ Consultation on the IAESB's Future Strategy and Priorities, www.ifac.org (11.12.2017).

Drumlak U., 2013, Ocena oferty kształcenia ustawicznego dla profesjonalnych księgowych w Polsce, Folia Pomer. Univ. Technol. Stetin, Oeconomica, 303(72), pp. 19-30.

Handbook of International Education Pronouncements, 2017, www.ifac.org (11.12.2017).

Kwiecień M., Harmonizacja i standaryzacja programów nauczania z dyscyplin naukowych rachunkowości, www.fundacja.edu.pl/organizacja/_referaty/29pdf (07.02.2012).

Memorandum on Lifelong Learning, Commission Staff Working Paper, October 2000, www.ue.com. (11.12.2017).

Micherda B., 2009, Międzynarodowe Standardy Edukacyjne IFAC inspiracją nowych zamierzeń edukacyjnych Stowarzyszenia Księgowych $w$ Polsce (samorządu zawodowych księgowych), Rachunkowość, 11, p. 53.

Micherda B., 2010, Wymagane kompetencje zawodowe biegłych rewidentów w Polsce w świetle Międzynarodowych Standardów Edukacyjnych IFAC, Zeszyty Naukowe UEK, 816, Kraków.

Międzynarodowe Standardy Edukacyjne 1-8 (zaktualizowane), https://www.skwp.pl/files/zg/mse/ IES1-8_Final_PL_2016.pdf(10.12.2017).

Ordinance of the Minister of Labor on the classification of professions and specialties for the needs of the labor market and its scope, DzU [Journal of Laws], 2014, item 1145.

Prewysz-Kwinto P., Voss G., 2016, Kursy i szkolenia jako element kształcenia pozaformalnego wedtug oceny pracodawców z województw pomorskiego i kujawsko-pomorskiego, Folia Pomer. Univ. Technol. Stetin., Oeconomica, 327(83)2, pp. 233-240.

Regulation No 58 of the Prime Minister of May 12, 2016 regarding the Interministerial Team for lifelong learning and the Integrated Qualifications System, M.P. 2016 item 447.

Regulation of the Minister of Finance of 6 November 2014 On Compulsory insurance of civil liability of entrepreneurs engaged in activities in the field of bookkeeping services, DzU [Journal of Laws] item 1616.

Resolution No. 757/202/2010 of the Presidium of the Main Board of the Association of Accountants in Poland of November 23, 2010 on the publication of the uniform text of Resolution No. 732/111/2009 of the Board of the Polish Association of Accountants from July 20, 2009 on the certification of the accounting profession.

Świetla K., 2014, Outsourcing usług księgowych $w$ świetle oczekiwań biur rachunkowych i ich klientów, Wydawnictwo Uniwersytetu Ekonomicznego w Krakowie, Seria specjalna: Monografie, nr 231, Kraków. 
Świetla K., Jonas K., 2015, Ryzyko w działalności gospodarczej w kontekście deregulacji zawodów księgowych, Zeszyty Naukowe Uniwersytetu Szczecińskiego, nr 855, Finanse, Rynki Finansowe, Ubezpieczenia nr 74, Szczecin, pp. 585-596.

Tissot P., 2004, Terminology of vocational training policy. A multilingual glossary for an enlarged Europe, Office for Official Publications of the European Communities, Luxembourg, p. 103.

Twelve years after: a call for a renewed Memorandum on Lifelong Learning, Brussels, 3 September 2012, www.1llplatform.eu (11.12.2017).

Uczenie się przez całe życie, 13 July 2016, www.kwalifikacje.gov.pl.

www.iaesb.org (7.12.2017).

www.ifac.org. (20.11.2017).

\section{ROLA EDUKACYJNA STOWARZYSZENIA KSIĘGOWYCH W POLSCE PO DEREGULACJI ZAWODU KSIĘGOWEGO}

Streszczenie: Ze względu na wszechobecnie zauważaną potrzebę specjalizacji w zakresie wykonywanych zawodów wzrasta rola edukacji. Dotyczy to między innymi zawodów księgowych mających istotne znaczenie jako zawody zaufania społecznego. W związku z takimi oczekiwaniami wzrasta rola kształcenia wśród grup zawodowych pracowników rachunkowości wszystkich szczebli. Celem artykułu było przedstawienie wymogów edukacyjnych dotyczących specjalizacji zawodowej księgowych na tle Międzynarodowych Standardów Edukacyjnych IFAC oraz w kontekście deregulacji zawodów księgowych w Polsce. Jako rozwiązanie zagadnienia problematyki prawidłowego kształcenia wskazano na rolę Stowarzyszenia Księgowych w Polsce w oparciu o prowadzone przez nie kursy i szkolenia mające na celu nie tylko podnoszenie kwalifikacji osób zajmujących się zawodowo rachunkowością, ale także wspieranie zasad etyki. Prowadzone kursy poddano analizie w przekroju ich uczestników na tle lat 2013-2016. Metodą przyjętą do realizacji założonego celu była analiza dostępnej literatury, obowiązujących regulacji oraz materiałów źródłowych udostępnionych przez SKwP. W oparciu o prowadzone badania stwierdzono, że mimo braku obowiązku certyfikacji zawodowej dla prowadzenia rachunkowości środowisko księgowych zauważa potrzebę nieustannego kształcenia i podejmuje w tym celu liczne działania służące podnoszeniu jakości wykonywanych świadczeń.

Słowa kluczowe: rachunkowość, nieustanne kształcenie, edukacja, certyfikacja, kursy zawodowe. 